\title{
Impact of Seasons on Soil Physico-Chemical Properties and Tea Yields Based on Enriched Sheep Manure Used in Kericho, Kenya
}

\author{
Rhoda Ruto ${ }^{1,2 *}$, Syphline Kebeney², John K. Bore1, David Chemei ${ }^{2}$ \\ ${ }^{1}$ Tea Research Institute, Kenya Agricultural and Livestock Research Organization, Kericho, Kenya \\ ${ }^{2}$ Department of Soil Science, The University of Eldoret, Eldoret, Kenya \\ Email: *rodaruto31@gmail.com
}

How to cite this paper: Ruto, R., Kebeney, S., Bore, J.K. and Chemei, D. (2019) Impact of Seasons on Soil Physico-Chemical Properties and Tea Yields Based on Enriched Sheep Manure Used in Kericho, Kenya. Journal of Agricultural Chemistry and Environment, 8, 184-199.

https://doi.org/10.4236/jacen.2019.83015

Received: May 15, 2019

Accepted: August 24, 2019

Published: August 27, 2019

Copyright $\odot 2019$ by author(s) and Scientific Research Publishing Inc. This work is licensed under the Creative Commons Attribution International License (CC BY 4.0).

http://creativecommons.org/licenses/by/4.0/

\section{Open Access}

\section{Abstract}

Tea (Camellia sinensis (L) O. Kuntze) is a perennial crop grown for beverage consumption. Its production is the leading foreign exchange earner in Kenya contributing about $26 \%$ foreign exchange and 4\% GDP. Nitrogen (N), Phosphorus $(\mathrm{P})$ and potassium $(\mathrm{K})$ are the recommended nutrients for tea production. However, their continuous use has been reported to have negative effect on soil physico-chemical properties and health. Sheep manure has been recommended in tea production for its soil $\mathrm{pH}$ buffering effect and increased tea yields. However, effects of sheep manure enriched with inorganic fertilizer on tea soils and yield have not been conclusively investigated. This study was established at KALRO-Tea Research Institute Kericho in Timbilil estate to determine the impact of seasonal variation on soil pysico-chemical properties and yields on enriched sheep manure used. Randomized complete block design (RCBD) experimental design was adopted with 14 treatments replicated thrice. The treatments were: control with no fertilizer use, NPK at $180 \mathrm{Kgs}$ $\mathrm{N} / \mathrm{ha} / \mathrm{yr}$, sheep manure only and two enriched sheep manure ratios of 4:1 and 8:1 which translates to a mixture of (4:1) 4 parts of sheep manure and 1 part of D.A.P inorganic fertilizer. Same applied to 8:1 ratio, respectively at rates of 60, 120, 180 and $240 \mathrm{Kgs}$ N/ha once per year. Data were subjected to ANOVA in GenStat statistical package and means separated by Duncan's multiple range tests at $\mathrm{P} \leq 0.05$ significance level. Results obtained showed that soil physico-chemical properties and tea yields were influenced significantly $(\mathrm{P} \leq$ 0.05 ) by treatments applied. Soil available water and organic matter were higher on enriched sheep manure 4:1 at 240 rate used while soil porosity and bulk density were not significantly affected. Total $\mathrm{N}$ and $\mathrm{P}$, increased with enriched sheep manure ratio of 4:1 at 240 rate while $\mathrm{K}^{+}, \mathrm{Ca}^{2+}, \mathrm{Mg}^{2+}, \mathrm{Mn}$ and $\mathrm{pH}$ increased with sole application of sheep manure at rate 180 and enriched 
sheep manure 8:1 at 180 rate. Tea yields increased with enriched sheep manure $4: 1$ ratios at the rates of 240 . The findings recommend enriched sheep manure 4:1 ratio at 240 rates to be adopted by tea farmers within Kericho region. Further studies involving different geographical locations are proposed.

\section{Keywords}

Seasons, Soil Physic-Chemical Properties, Enriched Sheep Manure, Tea Yields

\section{Introduction}

Tea is a perennial crop grown majorly for commercial purposes in Asia, Africa and South America. Major producers of the crop include China, India, Kenya, Sri Lanka and Indonesia. Kenya is the third leading producer of black tea after India and China in the world and the largest exporter of black CTC tea accounting for $23 \%$ world tea exports in 2017 [1]. The country's tea industry produced a total of 440 million Kgs of made tea in 2017 [1]. Tea is currently the leading foreign exchange earner in Kenya that contributed about $26 \%$ of the total export earnings and 4\% National Gross Domestic Product (GDP) and 17\% of the Agriculture GDP in 2017 [2]. Tea industry and its related activities have contributed to poverty eradication through employment leading to income earnings. Nitrogen $(\mathrm{N})$, Phosphorus $(\mathrm{P})$ and Potassium $(\mathrm{K})$ are the most critical nutrients in the fertilization programme of tea [3]. They also found out that NPK stimulates plant elongation and cell division hence leading to vigorous leaf shootings. However, some of the micronutrients elements for tea such as Manganese, Zinc, Copper and Iron have detrimental effects on black tea quality. Use of inorganic fertilizers on tea production has been reported to increase yield though it responds negatively to the soil physico-chemical properties and health [4]. This calls for adoption of organic fertilizers to help amend the soil physico-chemical components. Organic matter plays a critical role in stability of soil aggregates by binding together organic material such as bacterial waste products, organic gels, and fungal hyphae and soil worm secretions [5]. In addition, organic matter mixed with mineral improves soil physical properties like water holding capacity, pore space due to increases in the number of micropores and macropores in the soil by creating favorable condition for micro-organisms. Also, organic matter on decomposition releases nutrients into soil and has ability to retain and prevent nutrients from leaching into deeper soil layers. Tea fields mainly obtain organic materials from leaf fall and pruning though not enough to sustained tea farming hence there is a need for organic manure application [6]. In this regard, sheep manure is preferred because it does not raise the soil $\mathrm{pH}$ beyond 5.8 which is the highest limiting soil $\mathrm{pH}$ for the tea plants [7]. Sheep manure improves soil porosity, organic matter, particle density and lowers bulk density [8] though it was based on short rain seasons only hence led to study on three distinct seasons 
in Kericho. The study area experienced three distinct seasons [5], ranging from the warm dry season (Dec. to Mar.), cool wet season (Apr. to Aug.) and the warm wet season (Sept. to Nov.) The specific objective is to study the impact of seasonal variations on soil pysico-chemical properties based on of enriched sheep manure used in tea production in Kericho.

\section{Materials and Methods}

\subsection{Study Area}

The experiment was carried out at Tea Research Institute, Timbilil estate, Kericho; Sustainable Environment and Management Conservation department. The site lies along the incline of Mau forest ranges in the Rift valley at an altitude of $2178 \mathrm{~m}$ above mean sea level, latitude of $0^{\circ} 22^{\prime}$ South and a longitude of $35^{\circ} 21^{\prime}$ East. The annual rainfall ranges between $1200-2700 \mathrm{~mm}$ and mean monthly air temperatures of $16.1^{\circ} \mathrm{C}-19.5^{\circ} \mathrm{C}$ [9]. The area experiences three distinct seasons [5], ranging from the warm dry season (Dec. to Mar.), cool wet season (April to Aug.) and the warm wet season (Sept. to Nov.). The soils are well-drained, deep dusky red to dark reddish brown, friable clay with acid humic topsoil classed as humicnitisols (FAO/UNESCO1988 Classification).

\subsection{Experimental Design}

The study was superimposed on an on-going experiment investigating effects of different types of fertilizers on tea yields started in 1985 with TRFK $31 / 8$ planted high yielding clone. Randomized complete block design (RCBD) was used and the experiment had 14 treatments replicated three times. The entire experimental plot was divided into three blocks each containing 14 plots. The total experimental area was $157.67 \mathrm{~m}^{2}$. Each plot comprising of 10 tea bushes spaced at $4 \times 2 \times 2 \mathrm{~m}^{2}$. The whole plot was surrounded by complete guard-rows of tea bushes. Inorganic and enriched fertilizers were applied once a year. The sheep manure was standardized based on Nitrogen content. Sheep manure chemical composition was analyzed before application and experimental field plot soil texture analyzed.

\subsection{Field Data Collection and Laboratory Analysis}

\subsubsection{Soil Sampling and Preparation}

Soil sampling was done by randomly auguring three auger holes within each plot and extracting soils at different depths of $0-15 \mathrm{~cm}, 15-30$ and $30-45 \mathrm{~cm}$ from each auger hole. The three samples from each depth were mixed to form composite to give three samples from each plot. Soil sampling was done at three different seasons (December - March (warm dry), April - August (cool wet) and September - November (warm wet)). These samples were analyzed for $\mathrm{pH}$ before drying. The air-dried samples were crushed and sieved through $2 \mathrm{~mm}$ mesh for soil physical analysis and through $60 \mathrm{~mm}$ mesh for chemical analysis. The rainfall and temperature data for each sampling season was captured. 


\subsubsection{Determination of Soil Physical Properties}

The disturbed soil samples were saturated in water tray with a constant depth of $10 \mathrm{~mm}$ for 12 hours after which saturation mass was determined as per Klute method [10]. Samples were then transferred to a moisture extractor (soil moisture equipment Corp. USA) for moisture retention determination at 1 bar and 15 bars, respectively [10]. Soil available water content was calculated using the following:

$$
\mathrm{AWC}=\mathrm{FC}-\mathrm{PWP}
$$

where FC is the water available content at field capacity and ${ }_{\ominus} \mathrm{PWP}$ is the water content at permanent wilting point.

Soil texture and porosity were determined as per Klute [10], using the disturbed soil sample. Bulk density was carried out using core ring method and following laid down procedure on sampling and analysis. Organic matter analysis was carried out using 30\% hydrogen peroxide chemical for decomposition. Dried $10 \mathrm{~g}$ soil sample was weighed and $50 \mathrm{ml}$ of distilled water added. Floating particles removed followed by addition of $5 \mathrm{ml}$ of $30 \%$ hydrogen peroxide on boiling until frothing ceased. The content was dried in the oven at $105^{\circ} \mathrm{C}$ until constant weight was obtained. Organic matter was calculated as the difference between initial sample weight and final dry weight.

\subsubsection{Determination of Soil Chemical Properties}

Soil $\mathrm{pH}$ was determined using a glass electrode $\mathrm{pH}$ meter at a ratio of 1:2.5 soils to water. Total $\mathrm{N}$ was done by weighing $1 \mathrm{~g}$ of soil sample into digester tubes followed by addition of about $1 \mathrm{mls}$ Sulphuric acid then put in Kjeldahl digester for $4 \mathrm{hrs}$. After digestion, the samples are run in Vapodest machine for distillation and titration [11]. Nutrient elements $\mathrm{P}, \mathrm{K}, \mathrm{Mg}, \mathrm{Ca}$, and $\mathrm{Mn}$ were determined following TRFK soil chemical analysis manual and subjected to Inductive Couple Plasma Emission (ICPE)-Shimadzu (9000 series) for individual element levels determination.

\subsubsection{Tea Yields Determination}

Tea was plucked at $7-10$ days interval and their weight recorded per plot at every plucking round and seasons. The obtained yields were converted to $\mathrm{Kg}$ made tea per hectare per year using the formula $n=(\mathrm{a} \times 0.225) / b$. where $n$ is the green leaf yield per plot, $a$ is plant population per hectare while 0.225 is the factor converting green leaf to made tea [6] and $b$ is the number of plants per plot prior to statistical analysis.

\subsubsection{Statistical Data Analysis}

Data from tea soils were analyzed by ANOVA using SAS and GenStat software packages. Differences within the soil physical properties means were compared using Duncan's multiple tests while the soil chemical properties means were compared using (Least Significant Difference) test at a significance level of $5 \%(\mathrm{p}=0.05)$. 


\section{Results and Discussion}

\subsection{Soil texture and Chemical Composition of Sheep Manure}

The results in Table 1 showed the initial percentage of the physical components of soil used in the study. Sand gave the highest percentage (46.4\%) as compared to the other components. However, the clay soil possesses the commendable textural capacity as per the results shown in Table 1. This therefore indicates that the sand particles contribute to the well-drained tea plots and the clay soil texture helps to retain moisture used to the growth of tea [12].

The results in Table 2 show that the chemical composition of the sheep manure used was slightly basic $(\mathrm{pH}-8.76)$. The sheep manure had the largest percentage of potassium $(\mathrm{K}-4.53 \%)$ with low phosphorus $(\mathrm{P}-0.31 \%)$.

Figure 1 shows mean air temperature and total rainfall during the data collection period. The data was collected from TRI-agro-meteorological data station at TimbililEstate, Kericho about $1 \mathrm{~km}$ to experimental site. Season 3 had a large amount of rainfall and season 2 was the drier period (Figure 1). January to March 2017 months received little or no rain with high temperatures may affect plucking frequency and standards hence impacting negatively on tea bush productivity.

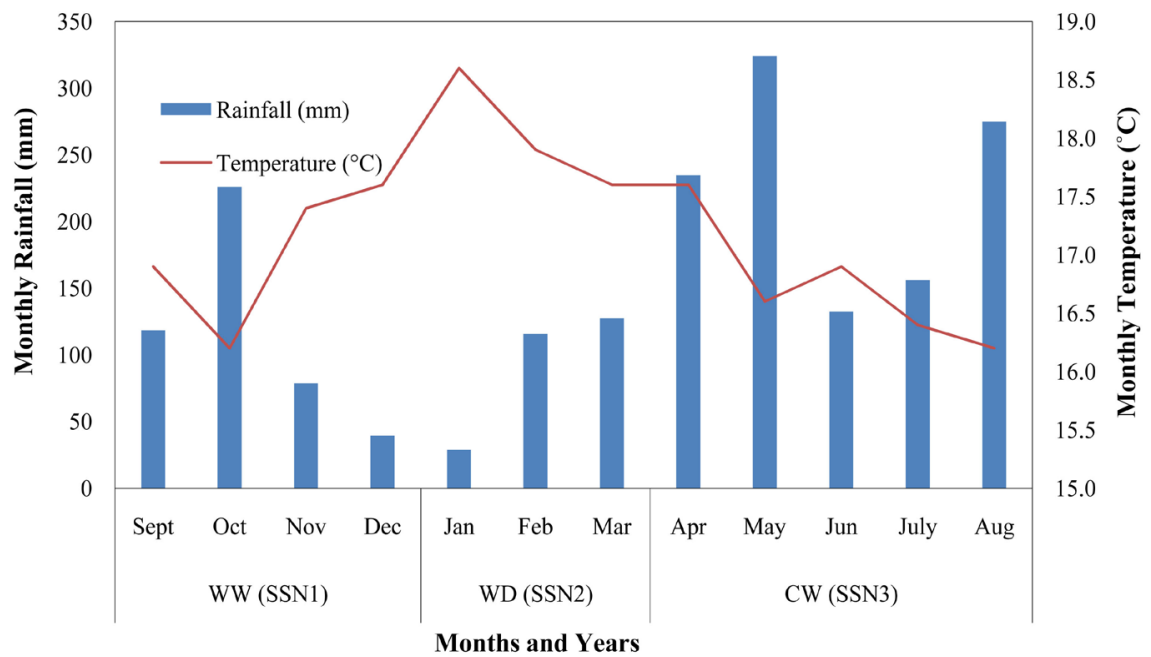

Figure 1. Climatic conditions during the sampling seasons.

Table 1. Soil particle size and textural grade.

\begin{tabular}{ccccc}
\hline Texture & Sand & Clay & Silt & Textural Grade \\
\hline Particle Size (\%) & 46.4 & 37.0 & 16.6 & Clay \\
\hline
\end{tabular}

Table 2. Chemical composition of sheep manure used.

\begin{tabular}{cccccccc}
\hline \multirow{2}{*}{$\begin{array}{c}\text { Sheep } \\
\text { Manure }\end{array}$} & $\mathrm{pH}$ & $\% \mathrm{~N}$ & $\% \mathrm{P}$ & $\% \mathrm{~K}$ & $\% \mathrm{Ca}$ & $\% \mathrm{Mg}$ & $\% \mathrm{Mn}$ \\
\cline { 2 - 7 } & 8.76 & 2.63 & 0.31 & 4.53 & 3.70 & 0.98 & 0.142 \\
\hline
\end{tabular}




\subsection{Effects of Enriched Sheep Manure and Fertilizers on Soil Physico-Chemical Properties}

\subsubsection{Effects of Enriched Sheep Manure and Fertilizers on Soil Physical Properties}

1) Soil water availability

There were significant differences $(\mathrm{p}<0.05)$ between the treatments in the first 2 seasons as shown in Table 3. Treatment SM gave the highest soil available water followed by enriched manure ratio 4:1 while NPK recorded the lowest (5.0\% and 7.3\%). This result suggests that enriched and organic manure improve soil water retention hence improve crop production. Similar findings were found by [13] that organic manure improves soil physical properties. NPK used gave the lowest soil available water to exhibit its negative effect on soil physical properties hence decreased soil water holding capacity. Related findings were reported by [14] on inorganic fertilizers study that high rates predispose tea plants to moisture stress through water inhibition and coupled with drought results may cause $14 \%-20 \%$ tea yields reduction and $6 \%-19 \%$ mortality rate [4]. Season 3 (WW) was not significant and had low soil available water compared to WD and CW seasons which might be due to high bulk density as a result of high rainfall (Figure 2). Though sheep manure improves soil physical properties, wet soil couple with tea plucking practices could have resulted in soil compaction which hinders water infiltration hence low soil water available.

Table 3. Influence of enriched sheep manure on the soil water available (\%) means in the soil.

\begin{tabular}{cccc}
\hline Treatment & Season 1 & Season 2 & Season 3 \\
\hline Control & & & \\
0 & $14.9 \mathrm{ab}$ & $14.9 \mathrm{ab}$ & $6.3 \mathrm{a}$ \\
SM & & & \\
60 & $13.5 \mathrm{ab}$ & $13.5 \mathrm{ab}$ & $7.1 \mathrm{a}$ \\
120 & $16.3 \mathrm{a}$ & $16.3 \mathrm{ab}$ & $8.8 \mathrm{a}$ \\
180 & $14.9 \mathrm{ab}$ & $11.5 \mathrm{ab}$ & $8.6 \mathrm{a}$ \\
240 & $18.9 \mathrm{a}$ & $15.7 \mathrm{ab}$ & $7.9 \mathrm{a}$ \\
Enriched 4:1 & & & \\
60 & $17.6 \mathrm{a}$ & $15.2 \mathrm{ab}$ & $9.2 \mathrm{a}$ \\
120 & $13.0 \mathrm{ab}$ & $13.0 \mathrm{ab}$ & $7.7 \mathrm{a}$ \\
180 & $10.1 \mathrm{bc}$ & $10.1 \mathrm{ab}$ & $8.1 \mathrm{a}$ \\
240 & $17.9 \mathrm{a}$ & $17.9 \mathrm{a}$ & $6.7 \mathrm{a}$ \\
Enriched 8:1 & & & \\
60 & $13.4 \mathrm{ab}$ & $13.4 \mathrm{ab}$ & $9.3 \mathrm{a}$ \\
120 & $6.9 \mathrm{~b}$ & $6.9 \mathrm{c}$ & $5.7 \mathrm{a}$ \\
180 & $13.6 \mathrm{ab}$ & $13.6 \mathrm{ab}$ & $10.4 \mathrm{a}$ \\
240 & $14.6 \mathrm{ab}$ & $14.6 \mathrm{ab}$ & $8.1 \mathrm{a}$ \\
NPK 180 & $7.3 \mathrm{~b}$ & $7.3 \mathrm{c}$ & $5.0 \mathrm{a}$ \\
p Value & 0.044 & 0.02 & 0.157 \\
DMRT (p $<0.05)$ & 7.443 & 6.176 & NS \\
\hline
\end{tabular}

Means followed by different letters down the column indicate significant differences at $p<0.05$ by least significant difference. 


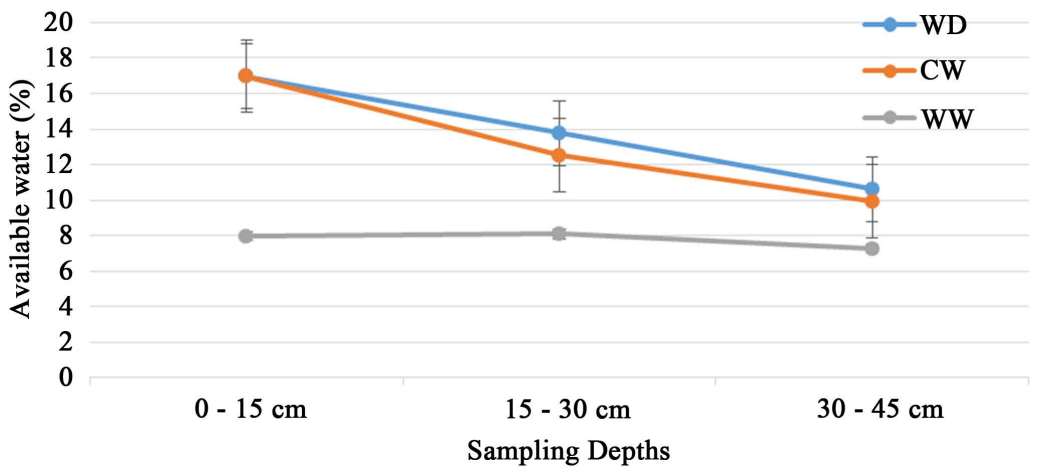

Figure 2. Influence of sampling depth on the available water in the soil. Season 1-Warm Dry (WD), December to March; Season 2-Cool Wet (CW), April to August; Season 3-Warm Wet (WW), September to November.

The results in Figure 2 showed significant $(\mathrm{p}<0.05)$ differences on soil available water with sampling depth used. There was slightly decreased in soil available water with increased in sampling depth across the seasons under study with a sharp dropped in WD and CW seasons. This trend implies that sheep manure improves water infiltration and water holding capacity hence available water in the soil. Similar results were reported on research done on roots characteristics of tea and silver oak that soil available water decreased on topsoil because tea plants feeder roots are within $30 \mathrm{~cm}$ deep [15] [16] hence water uptake within this region resulting. This reduced might have resulted in water capillary action hence decreased available water down the soil profile (Figure 2). This trend was more on WD season. Similar results were found out by [17]. The results showed, explicit low amount of available water during WW season and high on WD. This may be due to increased soil compaction during tea harvesting hence reduced pore space and water infiltration into the soil profile.

\section{2) Soil bulk density}

There were no significant $(\mathrm{p}<0.05)$ differences between the treatments on the bulk density in all the seasons under the study (Table 4). However, the obtained results are within the recommended bulk density limits (less than $1.6 \mathrm{~g} / \mathrm{cm}^{3}$ ) for soil agriculture [18]. This might be due to enriched sheep manure used which have improve soil organic matter and soil porosity hence desired bulk density. Moreover, significant differences were observed among the three sampling depths with the bulk density increasing with increasing depth and WW season giving high density (Figure 3). This might be due to heavy rainfall during AprilJune and human movement on tea plucking resulting in soil compaction hence increased bulk density. This is related to earlier studies found by [14] though on inorganic fertilizer use study that human traffic on tea harvesting increased bulk density down the soil profile.

\section{3) Soil porosity}

There were no significant $(\mathrm{p}<0.05)$ differences between the treatments on the soil porosity in all the three seasons of the study (Table 5). Similarly, soil porosity was not significantly $(\mathrm{p} \leq 0.05)$ affected by depths though there was slight 


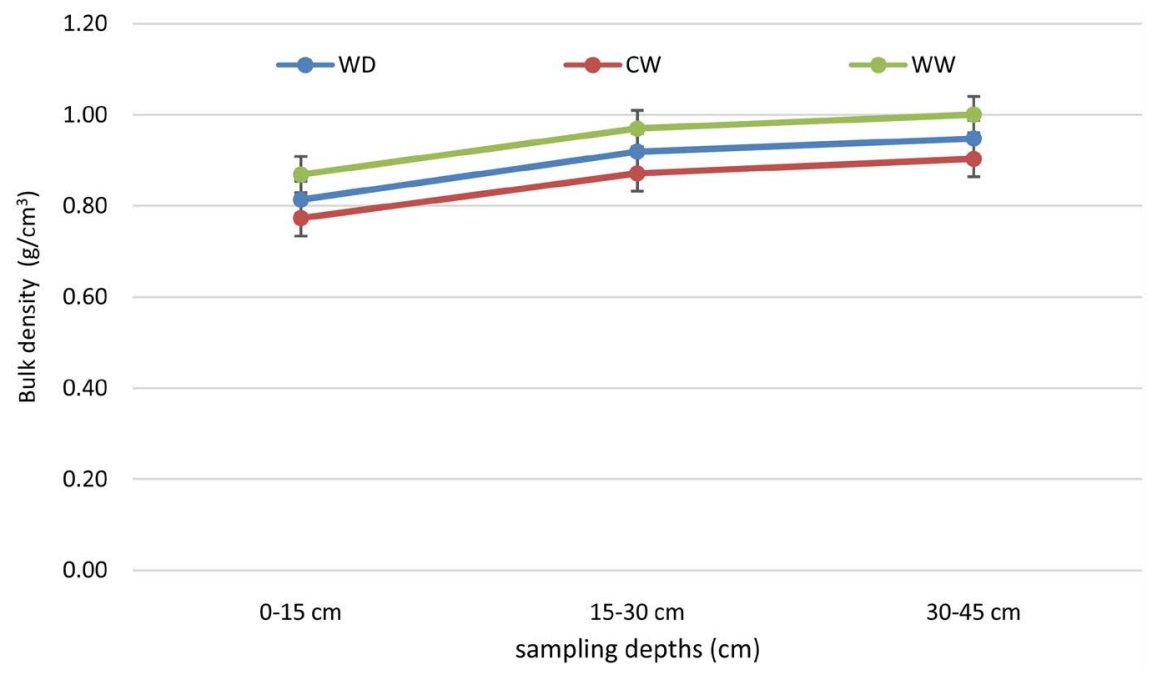

Figure 3. Influence of bulk density on sampling depths in the three seasons.

Table 4. Effect of different treatments on the bulk density $\left(\mathrm{g} / \mathrm{cm}^{3}\right)$ during the 3 seasons.

\begin{tabular}{|c|c|c|c|}
\hline Treatment & Season 1 & Season 2 & Season 3 \\
\hline \multicolumn{4}{|l|}{ Control } \\
\hline 0 & $0.89 \mathrm{a}$ & $0.84 \mathrm{a}$ & $0.92 \mathrm{a}$ \\
\hline \multicolumn{4}{|l|}{ SM } \\
\hline 60 & $0.94 a$ & $0.88 \mathrm{a}$ & $0.98 \mathrm{a}$ \\
\hline 120 & $0.88 \mathrm{a}$ & $0.84 \mathrm{a}$ & $0.93 a$ \\
\hline 180 & $0.91 \mathrm{a}$ & $0.86 a$ & $0.96 \mathrm{a}$ \\
\hline 240 & $0.87 \mathrm{a}$ & $0.83 \mathrm{a}$ & $0.93 a$ \\
\hline \multicolumn{4}{|l|}{ Enriched 4:1 } \\
\hline 60 & $0.89 \mathrm{a}$ & $0.85 a$ & $0.94 \mathrm{a}$ \\
\hline 120 & $0.85 a$ & $0.81 \mathrm{a}$ & $0.90 \mathrm{a}$ \\
\hline 180 & $0.95 a$ & $0.89 \mathrm{a}$ & $1.00 \mathrm{a}$ \\
\hline 240 & $0.90 \mathrm{a}$ & $0.84 \mathrm{a}$ & $0.95 a$ \\
\hline \multicolumn{4}{|l|}{ Enriched 8:1 } \\
\hline 60 & $0.91 \mathrm{a}$ & $0.87 \mathrm{a}$ & $0.95 \mathrm{a}$ \\
\hline 120 & $0.89 \mathrm{a}$ & $0.83 a$ & $0.96 a$ \\
\hline 180 & $0.93 a$ & $0.88 \mathrm{a}$ & $1.02 \mathrm{a}$ \\
\hline 240 & $0.85 a$ & $0.83 a$ & $0.98 \mathrm{a}$ \\
\hline NPK 180 & $0.87 \mathrm{a}$ & $0.84 \mathrm{a}$ & $0.91 \mathrm{a}$ \\
\hline p Value & 0.22 & 0.446 & 0.255 \\
\hline DMRT $(\mathrm{p}<0.05)$ & NS & NS & NS \\
\hline
\end{tabular}


Table 5. Effect of different treatments on the soil porosity (\%) during the 3 seasons.

\begin{tabular}{|c|c|c|c|}
\hline Treatment & Season 1 & Season 2 & Season 3 \\
\hline 0 & $53.01 \mathrm{a}$ & $37.56 \mathrm{a}$ & $55.73 \mathrm{a}$ \\
\hline \multicolumn{4}{|l|}{ SM } \\
\hline 60 & $55.07 \mathrm{a}$ & $38.22 \mathrm{a}$ & $54.42 \mathrm{a}$ \\
\hline 120 & $53.37 \mathrm{a}$ & $36.89 \mathrm{a}$ & $56.99 \mathrm{a}$ \\
\hline 180 & $51.06 \mathrm{a}$ & $43.33 \mathrm{a}$ & $54.46 \mathrm{a}$ \\
\hline 240 & $52.76 \mathrm{a}$ & $43.11 \mathrm{a}$ & $56.35 \mathrm{a}$ \\
\hline \multicolumn{4}{|l|}{ Enriched 4:1 } \\
\hline 60 & $51.90 \mathrm{a}$ & $42.67 \mathrm{a}$ & $53.59 \mathrm{a}$ \\
\hline 120 & $53.89 \mathrm{a}$ & $37.78 \mathrm{a}$ & $54.21 \mathrm{a}$ \\
\hline 180 & $52.44 \mathrm{a}$ & $39.11 \mathrm{a}$ & $57.11 \mathrm{a}$ \\
\hline 240 & $52.47 \mathrm{a}$ & $46.67 \mathrm{a}$ & $53.78 \mathrm{a}$ \\
\hline \multicolumn{4}{|l|}{ Enriched 8:1 } \\
\hline 60 & $51.59 \mathrm{a}$ & $42.89 \mathrm{a}$ & $54.19 \mathrm{a}$ \\
\hline 120 & $53.98 \mathrm{a}$ & $42.89 \mathrm{a}$ & $55.48 \mathrm{a}$ \\
\hline 180 & $51.84 \mathrm{a}$ & $46.00 \mathrm{a}$ & $54.15 \mathrm{a}$ \\
\hline 240 & $51.52 \mathrm{a}$ & $45.78 \mathrm{a}$ & $55.5 \mathrm{a}$ \\
\hline NPK 180 & $51.82 \mathrm{a}$ & $46.67 \mathrm{a}$ & $50.5 \mathrm{a}$ \\
\hline $\mathrm{p}$ Value & 0.835 & 0.081 & 0.52 \\
\hline DMRT $(\mathrm{p}<0.05)$ & NS & NS & NS \\
\hline
\end{tabular}

decline with increased sampling depth increased (Figure 4). This might be due to compaction as a result of field operation. This result is similar to earlier studies [19] [20] that human traffic caused soil compaction resulting in reduction of soil pore space hence decreased in soil water holding capacity. Enriched sheep manure used increased soil porosity which might due to the improved soil structure and addition of soil organic matter. Similar results were reported by [21] that organic manure adds a high percentage of organic matter into the soil.

4) Effects of enriched sheep manure and fertilizers on soil organic matter

The organic matter was significantly influenced by the treatments during the first and second seasons (Table 6). There were no significant differences between the treatments in the organic matter during the third season. The highest organic matter content $(0.81 \%)$ was recorded on enriched manure of ratio $8: 1$ at $60 \mathrm{Kg} \cdot \mathrm{N} / \mathrm{ha} / \mathrm{yr}$ rate. The lowest organic matter $(0.33 \%)$ was recorded on SM treatment during the WD season. The organic matter reduced significantly with increasing sampling depth (Figure 5). This might be attributed to leaf litter fall on topsoil hence build up soil organic matter. Early studies reported the same findings [22]. Enriched sheep manure increased soil organic matter compared to sheep manure alone to show that organic matter accumulation is related to tea leaves shootings and falling. This is expected because sheep manure 


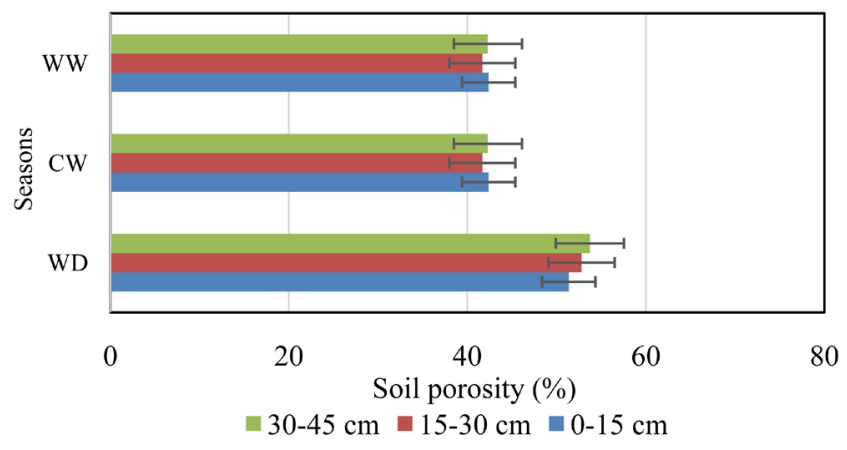

Figure 4. Influence of depth on the soil porosity (\%).

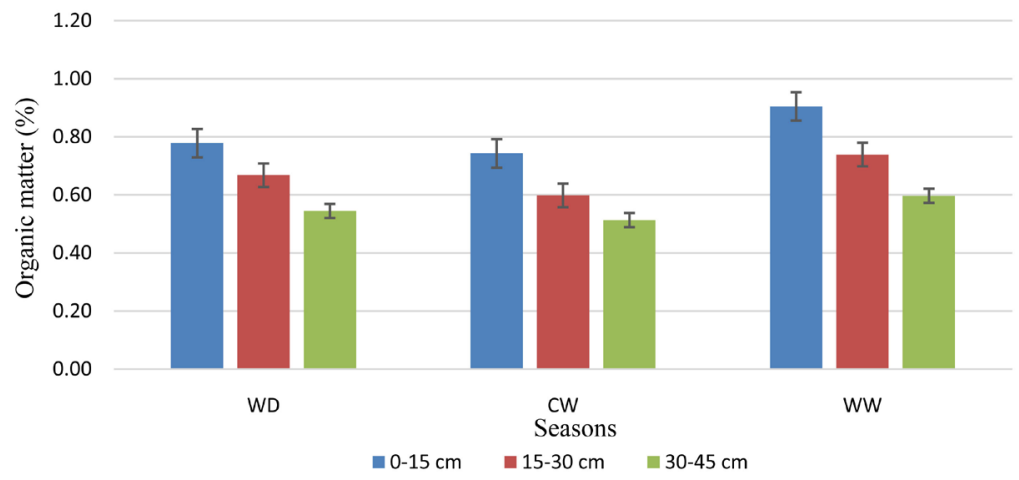

Figure 5. Influence of depth on the organic matter content in the study during the three seasons.

Table 6. Effect of different treatments on organic matter (\%) during the 3 seasons.

\begin{tabular}{cccc}
\hline Treatment Rates & Season 1 & Season 2 & Season 3 \\
\hline Control & & & \\
0 & $0.64 \mathrm{ab}$ & $0.69 \mathrm{ab}$ & $0.67 \mathrm{a}$ \\
SM & & & \\
60 & $0.70 \mathrm{a}$ & $0.33 \mathrm{c}$ & $0.77 \mathrm{a}$ \\
120 & $0.68 \mathrm{ab}$ & $0.52 \mathrm{~b}$ & $0.79 \mathrm{a}$ \\
180 & $0.71 \mathrm{a}$ & $0.56 \mathrm{~b}$ & $0.75 \mathrm{a}$ \\
240 & $0.67 \mathrm{ab}$ & $0.65 \mathrm{~b}$ & $0.76 \mathrm{a}$ \\
Enriched 4:1 & & & \\
60 & $0.66 \mathrm{ab}$ & $0.68 \mathrm{ab}$ & $0.75 \mathrm{a}$ \\
120 & $0.68 \mathrm{ab}$ & $0.68 \mathrm{ab}$ & $0.77 \mathrm{a}$ \\
180 & $0.64 \mathrm{ab}$ & $0.64 \mathrm{~b}$ & $0.74 \mathrm{a}$ \\
240 & $0.61 \mathrm{ab}$ & $0.62 \mathrm{~b}$ & $0.72 \mathrm{a}$ \\
Enriched 8:1 & & & \\
60 & $0.70 \mathrm{a}$ & $0.81 \mathrm{a}$ & $0.73 \mathrm{a}$ \\
120 & $0.65 \mathrm{ab}$ & $0.62 \mathrm{~b}$ & $0.77 \mathrm{a}$ \\
180 & $0.58 \mathrm{~b}$ & $0.65 \mathrm{~b}$ & $0.72 \mathrm{a}$ \\
240 & $0.65 \mathrm{ab}$ & $0.58 \mathrm{~b}$ & $0.69 \mathrm{a}$ \\
NPK 180 & $0.72 \mathrm{a}$ & $0.58 \mathrm{~b}$ & $0.80 \mathrm{a}$ \\
p Value & 0.047 & $<0.001$ & 0.163 \\
DMRT (p $<0.05)$ & 0.09008 & 0.1428 & NS \\
\hline
\end{tabular}

Means followed by different letters down the column indicate significant differences at $\mathrm{p}<0.05$ by Duncan multiple range test. 
supplied required nutrients for tea plants to produce vigorous leaves and on falling accumulates over time building on soil organic matter. Again sheep manure adds a high percentage of organic matter into the soil on application. Same was affirmed by [21].

Generally, organic manure was higher on enriched manure (combined sheep manure and NPK) application plots. This is in agreement with [21] [23] findings that combined application of NPK and organic manure (enriched) increased soil organic matter (SOM) than compound fertilizer (NPK) applied alone. Low organic matter in season two implies that during dry period soil condition and harsh climate favor increased rate of decomposition hence low organic matter in the soil. Similar results were found out by [24]. This condition results in N loss hence low tea yields.

\subsubsection{Soil Chemical Properties}

Table 7 indicates that soil chemical properties were significantly $(\mathrm{p} \leq 0.05)$ affected by the treatment applied. There was a positive increase in soil $\mathrm{pH}$ in the

Table 7. Effects of enriched Sheep manure and inorganic fertilizers on soil chemical properties.

\begin{tabular}{|c|c|c|c|c|c|c|c|c|}
\hline \multirow{2}{*}{ Treatment } & \multirow{2}{*}{ Rates } & \multicolumn{7}{|c|}{ Soil Available Nutrients $\operatorname{EXP}(\mathrm{N})^{-2}$} \\
\hline & & $\mathrm{pH}$ & $\mathrm{N} \%$ & $\mathrm{P}(\mathrm{ppm})$ & $\mathrm{K}(\mathrm{ppm})$ & $\mathrm{Ca}(\mathrm{ppm})$ & $\mathrm{Mg}(\mathrm{ppm})$ & Mn (ppm) \\
\hline Control & 0 & $1.92 \mathrm{f}$ & $0.18 \mathrm{abc}$ & $4.73 \mathrm{i}$ & $6.02 \mathrm{~d}$ & $6.81 \mathrm{f}$ & $5.34 \mathrm{f}$ & $5.54 \mathrm{bc}$ \\
\hline \multirow[t]{4}{*}{ SM } & 60 & $2.05 \mathrm{ab}$ & $0.18 \mathrm{abc}$ & 4.91ghi & $6.53 \mathrm{bc}$ & $7.34 \mathrm{bcd}$ & $6.07 \mathrm{abc}$ & $5.41 \mathrm{~cd}$ \\
\hline & 120 & $2.01 \mathrm{bcd}$ & $0.19 \mathrm{abc}$ & $4.89 \mathrm{ghi}$ & $6.71 \mathrm{ba}$ & $7.17 \mathrm{cde}$ & $5.97 \mathrm{bcd}$ & $5.31 \mathrm{~d}$ \\
\hline & 180 & $2.08 \mathrm{a}$ & $0.20 \mathrm{a}$ & $5.05 \mathrm{efg}$ & $6.80 \mathrm{a}$ & $7.78 \mathrm{a}$ & $6.27 \mathrm{a}$ & $5.47 \mathrm{~cd}$ \\
\hline & 240 & $2.02 \mathrm{bc}$ & $0.19 \mathrm{abc}$ & 5.16def & $6.71 \mathrm{ba}$ & $7.60 \mathrm{ab}$ & $6.22 \mathrm{ab}$ & $5.40 \mathrm{~cd}$ \\
\hline Enriched & 60 & $2.02 \mathrm{bcd}$ & $0.18 \mathrm{abc}$ & $5.04 \mathrm{efg}$ & $6.50 \mathrm{bc}$ & $7.26 \mathrm{cde}$ & $5.89 \mathrm{ecde}$ & $5.46 \mathrm{~cd}$ \\
\hline \multirow[t]{3}{*}{$4: 1$} & 120 & $1.99 \mathrm{~cd}$ & $0.17 \mathrm{bc}$ & $5.40 \mathrm{abc}$ & $6.43 c$ & $7.31 \mathrm{bcde}$ & $5.81 \mathrm{cde}$ & $5.49 \mathrm{bcd}$ \\
\hline & 180 & $1.96 \mathrm{ed}$ & $0.17 b c$ & $5.56 \mathrm{a}$ & $6.48 c$ & 7.02ef & $5.69 \mathrm{de}$ & $5.48 \mathrm{bcd}$ \\
\hline & 240 & $1.92 \mathrm{fe}$ & $0.17 \mathrm{abc}$ & $5.49 \mathrm{ab}$ & $6.38 \mathrm{c}$ & $7.14 \mathrm{cde}$ & $5.74 \mathrm{de}$ & $5.70 \mathrm{ab}$ \\
\hline Enriched & 60 & $1.98 \mathrm{~cd}$ & $0.19 \mathrm{abc}$ & $4.98 \mathrm{fgh}$ & $6.47 c$ & $7.16 \mathrm{ecd}$ & $5.88 \mathrm{cde}$ & $5.44 \mathrm{~cd}$ \\
\hline \multirow[t]{3}{*}{$8: 1$} & 120 & $1.93 \mathrm{e}$ & $0.17 \mathrm{c}$ & $5.20 \mathrm{cde}$ & $6.34 c$ & 7.08efd & $5.67 \mathrm{e}$ & $5.53 \mathrm{bcd}$ \\
\hline & 180 & $1.93 \mathrm{e}$ & $0.18 \mathrm{abc}$ & $5.32 \mathrm{bcd}$ & $6.53 \mathrm{bc}$ & $7.39 \mathrm{bcd}$ & $5.95 \mathrm{bcde}$ & $5.62 \mathrm{bc}$ \\
\hline & 240 & $2.01 \mathrm{bcd}$ & $0.2 .0 \mathrm{ab}$ & $5.34 \mathrm{bcd}$ & $6.46 c$ & $7.39 \mathrm{bcd}$ & $5.93 \mathrm{cde}$ & $5.57 \mathrm{bc}$ \\
\hline NPK 25:5:5 & 180 & $1.876 \mathrm{f}$ & $0.19 \mathrm{abc}$ & $4.82 \mathrm{hi}$ & $5.90 \mathrm{~d}$ & $6.45 \mathrm{~g}$ & $5.08 \mathrm{f}$ & $5.85 a$ \\
\hline CV\% & & 4.76 & 26.9 & 7.09 & 6.13 & 8.09 & 9.15 & 7.46 \\
\hline $\operatorname{LSD}(p \leq 0.05)$ & Trt & (D) Depth & (SN) Season & $\operatorname{Trt} \times \mathrm{D}$ & $\mathrm{SN} \times \mathrm{D}$ & $\mathrm{SN} \times \operatorname{Trt}$ & \multicolumn{2}{|c|}{$\mathrm{SN} \times \mathrm{D} \times \operatorname{Trt}$ (Interaction) } \\
\hline $\mathrm{pH}$ & 0.05 & NS & NS & NS & NS & NS & \multicolumn{2}{|c|}{ NS } \\
\hline $\mathrm{N}$ & NS & 0.03 & 0.012 & NS & 0.01 & NS & \multicolumn{2}{|c|}{ NS } \\
\hline $\mathrm{P}$ & $0.195^{\star * *}$ & $0.903^{* * *}$ & NS & $0.903^{* * *}$ & NS & NS & \multicolumn{2}{|c|}{ NS } \\
\hline $\mathrm{K}$ & 0.212 & $0.98^{\star * *}$ & $0.98^{* * *}$ & $0.093^{\star *}$ & NS & NS & \multicolumn{2}{|c|}{ NS } \\
\hline $\mathrm{Ca}$ & $0.313^{* * *}$ & $0.145^{\star * \star}$ & $0.145^{\star \star}$ & $0.142^{\star * *}$ & $0.142^{\star * *}$ & NS & \multicolumn{2}{|c|}{ NS } \\
\hline $\mathrm{Mg}$ & $0.285^{\star * *}$ & $0.132^{\star * *}$ & $0.132^{\star *}$ & NS & NS & NS & \multicolumn{2}{|c|}{ NS } \\
\hline $\mathrm{Mn}$ & $0.221^{* * *}$ & $0.102^{* * *}$ & $0.102^{\star * *}$ & NS & $0.095^{\star * *}$ & NS & \multicolumn{2}{|c|}{ NS } \\
\hline
\end{tabular}

${ }^{*}$ Means followed by different letters indicate significant differences at $(\mathrm{p} \leq 0.05)$ by least significant difference. 
treatments applied with sheep manure alone giving the highest value of 2.05 (5.77) followed by enriched ratio 4:1, 8:1, zero fertilizer used and the least NPK with 1.9 (4.7). This finding is supported by [21] [25] that organic manure has a tendency of increasing soil $\mathrm{pH}$ during oxidation process. High soil $\mathrm{pH}$ with organic manure may be due to organic anions complex the $\mathrm{Al}^{+3}$ ions that contribute to soil acidity.

Total $\mathrm{N}$ had no significant ( $\mathrm{p} \leq 0.05)$ difference on treatment used though there was an increase with the use of sheep manure alone and enriched fertilizer when compared with control. The highest recorded total $\mathrm{N}$ was $0.2 \%$ on sheep manure alone and enriched sheep manure (SM) at a ratio of 4:1 at rate 240 used while control was $0.18 \%$. These results might be due to slow release of nutrients in organic manure and high absorption rate of $\mathrm{N}$ by tea plants for production hence reduction of $\mathrm{N}$ in the soil. Similar results were found out by [18] that tea uses high rates of $\mathrm{N}$ fertilizer for optimum production.

$P$ was significantly $(\mathrm{p} \leq 0.05)$ increased with the use of enriched manure when compared to control and inorganic fertilizer used. These results show that organic manure increased soil $\mathrm{pH}$ hence availability of $\mathrm{P}$ nutrients in soil. Low soil $\mathrm{P}$ due to NPKS might be due to $\mathrm{P}$ fix due to acidic soil making it unavailable. $\mathrm{K}$, $\mathrm{Ca}, \mathrm{Mg}$ and $\mathrm{Mn}$ showed significant difference with increased availability on solely used SM and enriched manure. NPK obtained the least of these trace elements (K, Ca and $\mathrm{Mg}$ ) followed by control. This was expected because organic manures are rich in $\mathrm{K}$ content hence addition on mineralization producing acid humus that help in adsorption hence minimum leaching [25]. Decrease in soil $\mathrm{K}^{+}$content in NPK used might be due to low cations exchange and high aluminum accumulation leading to replacement of $\mathrm{K}$ by $\mathrm{NH}^{+}$because of same ionic radii. This result revealed that continuous use of NPK fertilizer in tea farms may result in deficiency of $\mathrm{K}$ nutrients hence enriched organic manure is necessary for tea sustainability. Reference [26] found out that organic manure is rich in micronutrients especially $\mathrm{K}$.

\subsection{Tea Yields}

The obtained results show that yields across the three seasons were highly significant (Table 8). Both enriched manure at ratio 240 gave the highest yield by out yielding control (zero) fertilizer and sheep manure alone (Table 8). These results imply that tea production cannot be achieved without fertilizer application. Application of organic manure when used alone cannot sustain tea production due to its slow release of nutrients on decomposition. Similar findings were reported by [25] [27]. Enriched sheep manure gave high yield compared to control, sheep manure alone and NPK. This is similar to [28] findings on enriched cattle manure used in tea. However, NPKS still gave high yields but season two showed the lowest yields as compared to other seasons (Table 8). This might be due to drought effect hence affecting soil water availability. This result is in line with [14] where prolonged drought caused death of tea bushes. Previous findings indicate that drought account for tea yield reduction of about $14 \%-20 \%$ 
Table 8. Influence of different enriched sheep manure on tea yield.

\begin{tabular}{|c|c|c|c|c|c|}
\hline Treatment & Ratios & SSN 1 & SSN 2 & SSN 3 & Means \\
\hline \multirow{5}{*}{ SM } & 0 & 517 & 563 & 1104 & 728 \\
\hline & 60 & 551 & 533 & 1092 & 725 \\
\hline & 120 & 725 & 603 & 1328 & 885 \\
\hline & 180 & 671 & 664 & 1295 & 877 \\
\hline & 240 & 649 & 647 & 1216 & 838 \\
\hline \multirow[t]{4}{*}{ Enriched 4:1 } & 60 & 712 & 702 & 1215 & 877 \\
\hline & 120 & 840 & 683 & 1773 & 1099 \\
\hline & 180 & 1003 & 613 & 1744 & 1120 \\
\hline & 240 & 1029 & 695 & 1784 & 1170 \\
\hline \multirow[t]{4}{*}{ Enriched 8:1 } & 60 & 673 & 637 & 1190 & 834 \\
\hline & 120 & 811 & 786 & 1718 & 1105 \\
\hline & 180 & 861 & 723 & 1435 & 1007 \\
\hline & 240 & 904 & 799 & 1786 & 1163 \\
\hline NPKS 25:55 & 180 & 922 & 781 & 1712 & 1136 \\
\hline Mean & & 777 & 674 & 1478 & \\
\hline CV (\%) & 16.91 & & & & \\
\hline \multirow[t]{2}{*}{ LSD $(\mathrm{p} \leq 0.05)$} & $\mathrm{TRT}^{* * *}$ & $\mathrm{SSN}^{* *}$ & $\mathrm{SSN}^{*} \mathrm{TRT}$ & & \\
\hline & 152 & 873 & 264 & & \\
\hline
\end{tabular}

and mortality rate of $6 \%-19 \%$ [29]. NPKS used gave high yields as enriched sheep manure to show the importance of $\mathrm{N}$ fertilizer on tea plants especially its associates with vigorous shootings of leaves contributing to high yields. Enriched sheep manure gave highest yields to show that it contains required nutrients for tea production, addition of soil organic matter and adsorptive power for cations and anions especially nitrates and phosphorus.

\subsection{Conclusion}

Organic manure has attracted much attention recently because of its ability to sustained soil health. Results obtained showed that organic manure restores soil properties though reduce tea yields when used alone. Enriched organic manure gave the increased soil available water (SAW) while NPK recorded the least in all the seasons. Enriched organic manure reduced soil bulk density and organic manure alone and NPK used increased bulk density. Soil organic matter increased with used of enriched manure and reduced with NPK and organic manure alone application in all seasons under review. These findings showed that enriched sheep manure improved soil physico-chemical properties and was evident through increased tea yields. Soil pH, N, P, K, Ca, Mg and Mn contents increased with enriched sheep manure and reduced with NKP fertilizer used. This was showed with improved tea yields though there was a positive record on in- 
organic fertilizer used. Generally tea yields increased on enriched sheep manure used compared to inorganic and control. These prove that tea sustainability can be enhanced through enriched organic manures used while maintaining soil health and reducing production cost. Farmers can be advised for application of enriched organic farming over the inorganic farming.

\section{Acknowledgements}

The authors appreciate the Kenya Agricultural and Livestock Research Organization-Tea Research Institute (KALRO-TRI) through the Institute Director for funding research work and availing fields for data collection. The University of Eldoret is also appreciated through the Vice Chancellor for the guidance provided during the development and execution of the full project.

\section{Conflicts of Interest}

The authors declare no conflicts of interest regarding the publication of this paper.

\section{References}

[1] ITC (2018) Annual Bulletin Statistics for 2018. International Tea Committee, London.

[2] FAO (2017) FAOSTAT-Tea Production 2017. FAO, Rome.

[3] Bonheure, D. and Willson, K.C. (1992) Mineral Nutrition and Fertilizers. In: Willson, K.C. and Clifford, M.N., Eds., Tea: Cultivation to Consumption, Chapman and Hall, London, Chapter 9, 269-329. https://doi.org/10.1007/978-94-011-2326-6_9

[4] Cheruiyot, E.K., Mumera, L.M., Ngetich, W.K, Hassanali, A. and Wachira, F.N. (2009) High Fertilizer Rates Increase Susceptibility of Tea to Water Stress. Journal of Plant Nutrition, 33, 115-125. https://doi.org/10.1080/01904160903392659

[5] Ng'etich, W.K. (1995) An Evaluation of Response of Some Kenyan Clones to Environment. PhD Thesis, Sisloe College, Cranfield University, Bedford.

[6] Anonymous (2002) Fertilizer and Nutrition. Tea Growers' Handbook. 5th Edition, Tea Research Foundation of Kenya, Nairobi.

[7] Kamau, D.M., Owuor, P.O. and Wanyoko, J.K. (2003) Long Term Effects of Rates and Types of Nitrogenous Fertilizers in High Yielding Clone AHP S 15/10 TEA (1): Yields and Nutrients Uptake. Tea, 24, 20.

[8] Chepkorir, B.M., Ann, S. and Mbira, K.G. (2018) Effect of Enriched Sheep Manure Rates on Physico-Chemical Parameters of Tea Soil in Timbilil Tea Estate, Kericho, Kenya. International Journal of Plant \& Soil Science, 25, 1-7. https://doi.org/10.9734/IJPSS/2018/44866

[9] Othieno, C.O. (1992) Soil. In: Willson, K.C. and Clifford, M.N., Eds., Tea: Cultivation to Consumption, Chapman and Hall, London, 137-140. https://doi.org/10.1007/978-94-011-2326-6_5

[10] Klute, A. (1986) Laboratory Methods. In: Klute, A., Ed., Methods of Soil Analysis. Part 1. Physical and Mineralogical Method, No. 9, Agronomy Services, No. 9, American Society of Agronomy Inc., Soil Science Society of America Inc., Madison, 635-662.

[11] Persson, J.A., Wennnerholm, M., Halloran, S.O., Tecator, F. and Osterberg, A. 
(2000) Handbook for Kjeldahl Digestion. A Recent Review of the Classical Method with Improvements. 3rd Edition, Tecator AB, Hoganas.

[12] FAO/UNESCO (1988) Soil Map of World. http://en.wikipedia.org/wiki/FAO_soilclassification\#FAO_Soilunits

[13] Omwoyo, W.N. (2017) Influence of Nitrogen Fertilizer Rates, Plucking Interval and Geographical Location of Production on Selected Micronutrients Levels of the Black Tea. Journal of Tea Science Research, 7, 1-10. https://doi.org/10.5376/jtsr.2017.07.0001

[14] Ng'etich, W.K. (1999) Effects of Different Applied Nitrogen Rates on Yield and Plant Survival during Periods of Water Stress. Tea, 20, 61-65.

[15] Owuor, P.O. (1997) Fertilizer Use in Tea: The Case of Nitrogen. Tea, 17, 53-59.

[16] Niranjana, K.S. and Viswanath, S. (2008) Roots Characteristics of Tea [Camellia sinensis (L.) O. Kuntze] and Silver Oak [Grevillearobusta) (A. Cunn)]. In a Mixed Tea Plantation at Munnar, Kerala. Journal of Tropical Agriculture, 46, 413.

[17] Ishii, D., Horiguchi, H., Hirai, Y., Yabu, H., Matsuo, Y., Ijiro, K., Tsuji, K., Shimozawa, T., Hariyama, T. and Shimomura, M. (2013) Water Transport Mechanism through Open Capillaries Analyzed by Direct Surface Modifications on Biological Surfaces. Scientific Reports, 3, Article ID: 3024. https://doi.org/10.1038/srep03024

[18] Jon, E.S. and Crim, F.J. (2015) An Introduction to Soil Concepts and the Role of Soil in Watershed Management. Journal of Contemporary Water Research \& Education, 154, 124. https://doi.org/10.1111/j.1936-704X.2015.03186.x

[19] Ng'etich, W.K. and Bore, K.J. (2002) Mechanical Harvesting of Tea. Effects on Soil Physical Properties. Tea, 21, 24-27.

[20] Ng'etich, W.K., Bore, K.J. and Cheserek, B. (2006) Biotic and Abiotic Factors Affecting Tea: A Review. Tea, 27, 61-65.

[21] Ayito, E.O., Otobong, B.I. and Kingsley, J. (2018) Effects of Neem-Based Organic Fertilizers, NPK and Their Combinations on Soil Properties and Growth of Okar (Abelmoschusesculentus) in a Degraded Littisol of Calabar, Nigeria. International Journal of Plant and Soil Science, 24, 1-10. https://doi.org/10.9734/IJPSS/2018/43027

[22] Alexander, B. and Jose, B. (2005) Importance of Organic Matter. Key to Drought Resistance Soil and Sustained Food and Production. Food and Agricultural Organization of the United Nations, Rome, 41-46.

[23] Ayeni, L.S. and Ezeh, O.S. (2017) Comparative Effect of NPK 20:10:10, Organic-Mineral Fertilizer on Soil Chemical Properties, Nutrients Uptake and Yield of Tomato. Applied Tropical Agriculture, 22, 111-116.

[24] Rice, J.V. (2002) Natural Factors Influencing the Amount of Organic Matter. http://www.fao/org./docrep/009/a0100e/a0/00e06.htm

[25] Kekana, V.M., Kamau, D.M., Tabu, I.M., Nyabundi, K.W. and Wanyoko, J.K. (2012) Effects of Varying Ratios of Enriched Manures on Nutrient Uptake, Soil Chemical Properties, Yields and Quality of Clonal Tea. Tea, 33, 18-29.

[26] Mokaya, B.N. (2016) Effects of Varying Rates of Organic and Inorganic Fertilizers on Growth, Yield and Nutrients Use Efficiency of Clonal Tea (Camellia sinensis L. (O) Kuntze). MSC Thesis, University of Nairobi, Nairobi.

[27] Nyabundi, K.W. and Boiwa, M.C. (2015) Effects of Fertilizer Types and Rates on Nitrogen Use Efficiency, Yield and Nitrogen Content. Tea, 36, 65-71.

[28] Kenana, V.M. and Kamau, D.M. (2015) Effect of Varying Ratios and Rates of Enriched Cattle Manure on Leaf Nitrogen Content, Yield and Quality of Tea (Ca- 
mellia sinensis). Tea, 7, 177-178. https://doi.org/10.5539/jas.v7n5p175

[29] Cheruiyot, E.K., Mumera, L.M., Ngetich, W.K., Hassanali, A. and Wachira, F.N. (2008) Threshold Soil Water Content for Growth of Tea (Camellia sinsensis L. O. Kuntez). Tea, 29, 29-38. 